\title{
Crude protein from spirulina increases the viability of CCD-986sk cells via the EGFR/MAPK signaling pathway
}

\author{
PING LIU ${ }^{1}$, MIN-KYEONG LEE ${ }^{2}$, JEONG-WOOK CHOI ${ }^{2}$, \\ YOUN-HEE $\mathrm{CHOI}^{2,3}$ and TAEK-JEONG NAM ${ }^{1,2}$
}

\author{
${ }^{1}$ Department of Food Science and Nutrition, Pukyong National University, Busan 48513; ${ }^{2}$ Institute of Fisheries Sciences, \\ Pukyong National University, Busan 46041; ${ }^{3}$ Department of Marine Bio-Materials and Aquaculture, \\ Pukyong National University, Busan 48513, Republic of Korea
}

Received August 28, 2018; Accepted December 7, 2018

DOI: $10.3892 /$ ijmm.2018.4025

\begin{abstract}
Spirulina, an edible blue-green alga, has great potential for various applications in human health, possibly including reduced skin aging. The mechanisms by which spirulina crude protein (SPCP) may influence human skin fibroblast viability are not yet understood; therefore, a human dermal fibroblast cell line (CCD-986sk) was used as a cell model system to study the influence of SPCP on human skin fibroblast viability. An enzyme-linked immunosorbent assay showed that collagen formation improved in SPCP-treated cells in a dose-dependent manner, while elastase activity was decreased. In addition, western blot analysis showed a dose-dependent decrease in the expression of the aging-associated gene matrix metalloproteinase-8, a collagen-degradative enzyme. It was also shown that SPCP upregulated epidermal growth factor receptor (EGFR) activity, leading to activation of the mitogen-activated protein kinase (MAPK)/extracellular signal-regulated kinase (ERK) signaling pathway. Together, these results demonstrated that SPCP increases human fibroblast viability by activation of the EGFR/MAPK signaling pathway. This contribution sheds light on the molecular mechanism for SPCP increasing the viability of human skin cell and provides a potential efficient cosmeceutical for protecting human skin.
\end{abstract}

\section{Introduction}

The blue-green microalga, spirulina (Arthrospira platensis), has recently been used as a food source due to its high protein content and nutritional value $(1,2)$. Spirulina has been extensively studied owing to its nutrient composition, which has

Correspondence to: Professor Taek-Jeong Nam, Department of Food Science and Nutrition, Pukyong National University, 45 Yongso-ro, Nam-Gu, Busan 48513, Republic of Korea E-mail: namtj@pknu.ac.kr

Key words: human dermal fibroblasts, spirulina crude protein, collagen, epidermal growth factor receptor, mitogen activated protein kinase/extracellular signal-regulated kinase signaling pathway been demonstrated to effectively treat a number of medical conditions (such as anti-cancer, inhibiting senescence and enhancing the non-specific cellular immune function) (3). Spirulina has also been reported to have an inhibitory effect on ultraviolet B-induced skin inflammation $(4,5)$. It has an antioxidant defense system that removes reactive oxygen species that may damage cells (6-8). Previous studies have reported that early skin aging can be repaired using an extract from microalgae, which prevents wrinkle formation and has a tightening effect (9); thus, such extracts have been used in many skin care products (10). Despite these benefits, the mechanisms underlying the protective effects of spirulina crude protein (SPCP) on skin cells are largely unknown.

The prevention of skin aging has attracted considerable attention, both scientifically and cosmetically. Owing to the disruption of its barrier function over time, the aged skin has a dry appearance and has an increased risk of skin disorders (11). Deterioration of skin elasticity and the skin extracellular matrix (ECM) are characteristics of the aging skin. Reduction of the elastic properties in dermal layers can lead to the formation of wrinkles in humans and animals (12-14). Furthermore, three-dimensional alteration of elastic fibers indicates the marked and continuous upregulation of an elastin-degrading enzyme in the aging skin. The ECM of the dermis consists of collagen and is produced by fibroblasts (15). In particular, type I collagen is the most prevalent of the fibril-forming collagens (16,17). Matrix metalloproteinase-8 (MMP-8), a zinc-dependent endopeptidase, is present at sites of acute inflammation and potently degrades type I collagen $(18,19)$. Anti-wrinkle strategies therefore include enhancing skin elasticity and collagen content. Additionally, the promotion of proliferation and differentiation of human dermal fibroblasts can also help delay the aging process of the skin (20-22).

Fibroblast proliferation is regulated by many growth factors. Epidermal growth factor receptor (EGFR) is one of the most well-known cell proliferation proteins in the body (23), and it has been reported that EGFR levels in dermal fibroblasts decline with age (21). A previous study has demonstrated that EGFR inhibitors may promote human skin aging (24). Green et al (25), reported that EGFR expression levels are lower in the dorsal skin of old rats (day 23 or day 51) compared with younger ones (neonatal, day 1). Furthermore, EGFR 
expression levels were lower in old human dermal fibroblasts (Passage 16 or greater) compared with young human fibroblasts (Passage 9 or less) (26). The mitogen-activated protein kinase (MAPK) signaling pathway is one of the EGFR-activated downstream signaling pathways and is an important regulator of cell proliferation $(27,28)$. Therefore, in the present study, the effects of SPCP on the EGFR/MAPK signaling pathway in CCD-986sk cells were investigated. These results shed light on the molecular mechanism for SPCP increasing the viability of human skin cell and provide a potential efficient cosmeceutical for protecting human skin.

\section{Materials and methods}

Preparation of SPCP. Spirulina powder [40 g, New Zealand Nutritionals (2004) Ltd., Burnside Christchurch, New Zealand] was soaked in distilled water (11) and mixed for $4 \mathrm{~h}$ at room temperature. Following centrifugation at $2,399 \times \mathrm{g}$ at $4^{\circ} \mathrm{C}$ for $10 \mathrm{~min}$, it was incubated for $4 \mathrm{~h}$ with three volumes of ethanol at $4^{\circ} \mathrm{C}$. The solution was centrifuged at $2,399 \times \mathrm{g}$ at $4^{\circ} \mathrm{C}$ for $10 \mathrm{~min}$. The supernatant was filtered and concentrated using rotary evaporation at $40^{\circ} \mathrm{C}(29)$, and the concentrated solution was precipitated overnight with $80 \%$ saturated $\left(\mathrm{NH}_{4}\right)_{2} \mathrm{SO}_{4}$ solution at $4^{\circ} \mathrm{C}$. After standing at $4^{\circ} \mathrm{C}$ for $10 \mathrm{~min}$, the precipitate was dissolved in and dialyzed against distilled water. The dialysate was concentrated (Rotary evaporator, $40^{\circ} \mathrm{C}$ ) and freeze-dried $(1000 \mu \mathrm{g} / \mathrm{ml})$, and subsequently used as the SPCP preparation in subsequent experiments.

Assessment of the SPCP protein profile. The protein profile of the SPCP was analyzed by subjecting the extract to SDS-PAGE and Coomassie Brilliant Blue staining. In brief, the SPCP were mixed with $5 \mathrm{x}$ sample loading buffer $[50 \mathrm{mM}$ Tris- $\mathrm{HCl}$, $2 \%$ SDS, $10 \%$ Glycerol, 0.02\% Bromophenol blue (BPB), $5 \%$ 2-mercaptoethanol], and SPCP containing $75 \mu \mathrm{g}$ of protein were separated by $15 \%$ SDS-PAGE. The gels were stained with Coomassie Brilliant Blue for $1 \mathrm{~h}$ at room temperature and washed with destaining solution until the bands appeared (3). SPCP of $20 \mathrm{kDa}$ and $\sim 16 \mathrm{kDa}$ were performed a quadrupole time of flight mass spectrometry (Q-TOF MS/MS) analysis by Peptron, Inc. (Daejeon, Korea).

Cell culture. The CCD-986sk human dermal fibroblast cell line (CRL-1947; American Type Culture Collection, Manassas, VA, USA), derived from normal female skin tissue, was cultured in Dulbecco's Modified Eagle's Medium (Gibco; Thermo Fisher Scientific, Inc., Waltham, MA, USA) with $10 \%$ fetal bovine serum (Gibco; Thermo Fisher Scientific, Inc.) and $1 \%$ penicillin/streptomycin at $37^{\circ} \mathrm{C}$ with $5 \% \mathrm{CO}_{2}$ in a saturated humidified incubator (30). The CCD-986sk cells were cultured to $60-80 \%$ confluency in $100-\mathrm{mm}$ diameter plates, and the medium was replaced every 2 days.

Cell viability assay. Cell viability was determined using the CellTiter 96 AQueous One Solution Reagent (Promega Corporation, Madison, WI, USA). CCD-986sk cells were seeded in a 96-well plate at a density of $0.5 \times 10^{4}$ cells/well. After $24 \mathrm{~h}$ of incubation, the cells were incubated with serum-free medium (SFM) for $4 \mathrm{~h}$ at $37^{\circ} \mathrm{C}$. Serum contains several hormones, which are stimulatory for cell growth and mask the effects of SPCP. To avoid the complication, SFM was used in all of the groups tested (control and SPCP-treated groups) (31). Subsequently, various concentrations of SPCP $(6.25,12.5$ or $25 \mu \mathrm{g} / \mathrm{ml}$ in SFM) or SFM alone (control) were used to treat the cells. The cells were further cultured for $24 \mathrm{~h}$. Subsequently, the cells were exposed to the 3-(4,5-dimethylthiazol-2-yl)-5-(3-caboxymethoxy-phenyl)-2-(4-sulfonyl)-2H-tetrazolium (MTS) assay solution at $37^{\circ} \mathrm{C}$ for $30 \mathrm{~min}$, and the optical density at $490 \mathrm{~nm}$ was measured using a Synergy HTX microplate reader (BioTek Instruments, Inc., Winooski, VT, USA). Data are expressed as the percentage of viable SPCP-treated cells compared with viable cells in the SFM-treated control.

Elastase activity. Elastase activity was measured using N-succinyl-Ala-Ala-Ala-p-nitroanilide (Sigma-Aldrich; Merck KGaA, Darmstadt, Germany). Cells were seeded into 6 -well plates at a density of $5 \times 10^{4}$ cells/well. After $24 \mathrm{~h}$ of culture, the cells were incubated with SFM for an additional $4 \mathrm{~h}$ at $37^{\circ} \mathrm{C}$. Various concentrations of $\operatorname{SPCP}(6.25,12.5$ or $25 \mu \mathrm{g} / \mathrm{ml}$ in SFM) or SFM alone (control) were used to treat the cells, and they were further cultured for $24 \mathrm{~h}$. The cells were collected in radioimmunoprecipitation assay buffer (iNtRON Biotechnology, Seongnam, Korea) with $1 \%$ protease inhibitor using a cell scraper. The cell supernatant was collected by centrifugation $\left(1,8341 \mathrm{x} \mathrm{g} ; 4^{\circ} \mathrm{C}\right.$; $10 \mathrm{~min})$. Subsequently, the supernatant $(98 \mu \mathrm{l})$ and $25 \mathrm{mg} / \mathrm{ml}$ $\mathrm{N}$-succinyl-Ala-Ala-Ala-p-nitroanilide $(2 \mu \mathrm{l})$ were added to each well (32). After incubation at $37^{\circ} \mathrm{C}$ for $30 \mathrm{~min}$, the optical density at $410 \mathrm{~nm}$ was measured using a Synergy HTX microplate reader (BioTek Instruments, Inc.). Data are expressed as a percentage of elastase activity in treated cells compared with the SFM-treated control.

Procollagen type I C-peptide (PIP) solid phase enzyme immunoassay. The level of procollagen was measured with the Takara MK101 kit (Takara Bio, Inc., Otsu, Japan). Cells were seeded into 6-well plates at a density of $5 \times 10^{4}$ cells/well. After $24 \mathrm{~h}$ of incubation, the cells were incubated with SFM for $4 \mathrm{~h}$ at $37^{\circ} \mathrm{C}$, followed by treatment with various concentrations of SPCP $(6.25,12.5$, or $25 \mu \mathrm{g} / \mathrm{ml}$ in SFM) or SFM (control) for an additional $24 \mathrm{~h}$. The cell medium was collected and centrifuged $\left(13,475 \mathrm{x} \mathrm{g} ; 4^{\circ} \mathrm{C} ; 10 \mathrm{~min}\right)$. Subsequently, $100 \mu \mathrm{l}$ of antibody-peroxidase conjugate solution (included in the Takara MK101 kit) and $20 \mu 1$ of supernatant were added to each well. After incubation for $3 \mathrm{~h}$ at $37^{\circ} \mathrm{C}$, each well was washed four times using $400 \mu 1$ of PBS each time. A total of $100 \mu \mathrm{l}$ of 3,3',5,5'-tetramethylbenzidine substrate solution was then added to each well and incubated for $15 \mathrm{~min}$ at room temperature (32). The reaction was terminated with $100 \mu \mathrm{l}$ of stop solution $\left(1 \mathrm{~N} \mathrm{H}_{2} \mathrm{SO}_{4}\right)$. The absorbance at $450 \mathrm{~nm}$ was measured using a Synergy HTX microplate reader (BioTek Instruments, Inc.).

Western blotting. CCD-986sk cells were cultured to $50-60 \%$ confluency and then incubated with SFM for $4 \mathrm{~h}$ at $37^{\circ} \mathrm{C}$. The medium was replaced with three concentrations of $\operatorname{SPCP}(6.25,12.5$ or $25 \mu \mathrm{g} / \mathrm{ml}$ in SFM) or SFM (control). The cells were cultured for another $24 \mathrm{~h}$ and proteins were extracted using radioimmunoprecipitation lysis buffer 
(iNtRON Biotechnology) with $1 \%$ protease inhibitor, followed by centrifugation at $18,341 \mathrm{x} \mathrm{g}$ at $4^{\circ} \mathrm{C}$ for $10 \mathrm{~min}$. Protein concentrations were determined using the Bicinchoninic assay. The protein samples $(30 \mu \mathrm{g})$ were resolved by 7.5-12.5\% SDS-PAGE and subsequently transferred electrophoretically to polyvinylidene difluoride membranes. After washing with methanol, the membranes were blocked with $1 \%$ bovine serum albumin (MP Biomedicals LLC, USA) in TBS + Tween-20 [10 mM Tris- $\mathrm{HCl}, 150 \mathrm{mM} \mathrm{NaCl}(\mathrm{pH} 7.5)$ and $0.1 \%$ Tween-20] and incubated overnight at $4^{\circ} \mathrm{C}$ with specific primary antibodies (all 1:1,000) (33). After washing twice, the membranes were incubated for $2 \mathrm{~h}$ at room temperature with the secondary antibodies (all 1:10,000). The second antibodies were horseradish peroxidase (HRP)-conjugated anti-rabbit lg G (cat. no. 7074S; Cell Signaling Technology, Inc., Beverly, MA, USA), donkey anti-goat $\lg$ (cat. no. A50-101p; Bethyl Laboratories, Inc., MA, USA) and anti-mouse $\lg$ G (cat. no. 7076S; Cell Signaling Technology, Inc.). The following primary antibodies obtained from Santa Cruz Biotechnology, Inc., were used: Goat anti-phosphorylated (p)-EGFR antibody (cat. no. sc-12351), goat anti-EGFR antibody (cat. no. sc-03), mouse anti-Shc antibody (cat. no. sc-967), rabbit anti-growth factor receptor bound protein (GRB) 2 antibody (cat. no. sc-255), rabbit anti-Son of sevenless homolog (Sos) antibody (cat. no. sc-259), rabbit anti-H-Ras antibody (cat. no. sc-520), mouse anti-p-Mitogen-activated protein kinase kinase (MEK)-1/2 antibody (cat. no. sc-81503), mouse anti-MEK-1/2 antibody (cat.no. sc-81504), mouse anti-p-extracellular signal-regulated kinase (ERK) antibody (cat. no. sc-7383), mouse anti-ERK 1 antibody (cat. no. sc-271269), rabbit anti-ERK-2 antibody (cat. no. sc-154), and rabbit anti-GAPDH antibody (cat. no. sc-25778). The signals were detected using an Enhanced Chemiluminescence western blot kit (Thermo Fisher Scientific, Inc.) using a bioanalytical imaging system (Azure Biosystems, Dublin, CA, USA). The densities of the bands which normalized to GAPDH were analyzed using Multi-Gauge software, v.3.0 (Fujifilm Life Science, Tokyo, Japan).

Statistical analysis. For all assays, at least three independent experiments were performed. The mean \pm standard deviation of the expression values was calculated using Excel software v.2007 (Microsoft Corporation, Redmond, WA, USA). The differences among multiple groups were evaluated using one-way analysis of variance followed by Bonferroni post hoc test using SPSS statistical software for Windows, v.20.0 (IBM Corp., Armonk, NY, USA).

\section{Results}

Positive effects of SPCP on human skin cell growth. SPCP is a complex mixture of proteins, which were separated by SDS-PAGE and stained with Coomassie Brilliant Blue revealing $\sim 20$ and $\sim 16 \mathrm{kDa}$ bands (Fig. 1). The two bands were analyzed by Q-TOF MS/MS. The results revealed that the $20 \mathrm{kDa}$ band didn't correspond to any known protein while the $\sim 16 \mathrm{kDa}$ protein band was $\mathrm{C}$-phycocyanin $\alpha$ chain, which has many pharmacological benefits (34). To investigate the effects of SPCP on the viability of CCD-986sk cells, an MTS assay on cells treated with various doses of SPCP was performed. The viability of cells treated with $6.25,12.5$ or

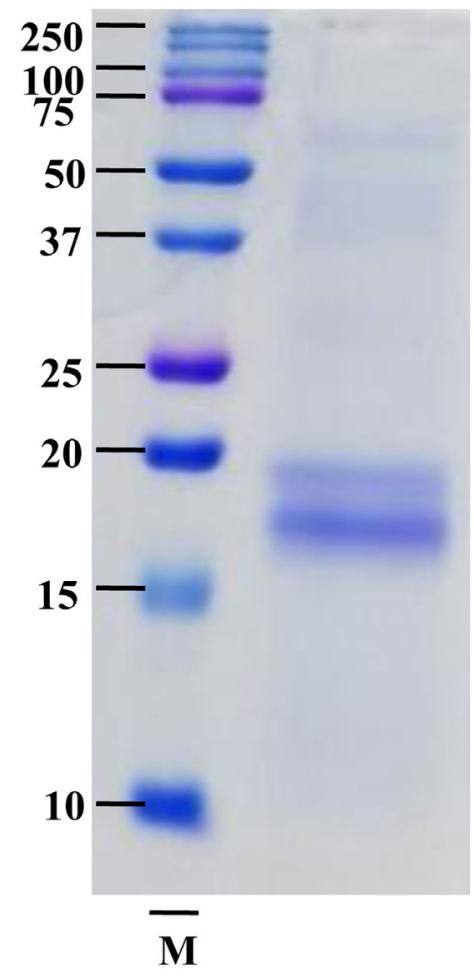

Figure 1. Protein profile of SPCP. SPCP was loaded on a $15 \%$ polyacrylamide gel and stained with Coomassie Brilliant Blue. M, marker.

$25 \mu \mathrm{g} / \mathrm{ml}$ SPCP increased by $18 \pm 4.41 \%, 33 \pm 1.62 \%(\mathrm{P}<0.01)$ and $42 \pm 2.82 \%(\mathrm{P}<0.001)$, respectively, compared with the control (Fig. 2). Together, the results indicated that SPCP effectively promoted the growth of CCD-986sk cells at in a dose-dependent manner.

Inhibitory effect of SPCP on elastase activity. Elastase activity in CCD-986sk cells following various treatments with SPCP was measured. Compared with the control, SPCP treatment significantly decreased the elastase activity in a dose-dependent manner $(\mathrm{P}<0.05$ or $\mathrm{P}<0.001$; Fig. 3$)$, with a maximum decrease of $42 \pm 6.15 \%$ observed in cells treated with $25 \mu \mathrm{g} / \mathrm{ml} \mathrm{SPCP}$.

Effect of SPCP on PIP levels. To determine whether SPCP affected the secretion of PIP, secreted PIP levels were measured using ELISA. SPCP treatments significantly increased PIP levels in a dose-dependent manner $(\mathrm{P}<0.05$ or $\mathrm{P}<0.001$; Fig. 4A). Compared with the basal level of $77 \pm 2.78 \mathrm{ng} / \mathrm{ml}$, PIP concentrations of $100 \pm 2.36,121 \pm 9.45$ and $187 \pm 7.92 \mathrm{ng} / \mathrm{ml}$ were induced by $6.25,12.5$, and $25 \mu \mathrm{g} / \mathrm{ml}$ SPCP, respectively. This result indicated that SPCP promoted the secretion of PIP.

Western blotting was used to determine the effect of SPCP on MMP-8 expression in CCD-986sk cells. MMP-8 protein expression levels were significantly decreased by SPCP treatment in a dose-dependent manner $(\mathrm{P}<0.001$; Fig. 4B). These results suggested that SPCP promoted the synthesis of collagen and inhibited the expression of MMP-8.

Activation of the EGFR signaling pathway by SPCP in $C C D-986$ sk cells. As SPCP treatment was revealed to enhance the viability of CCD-986sk cells (Fig. 2), the potential regula- 


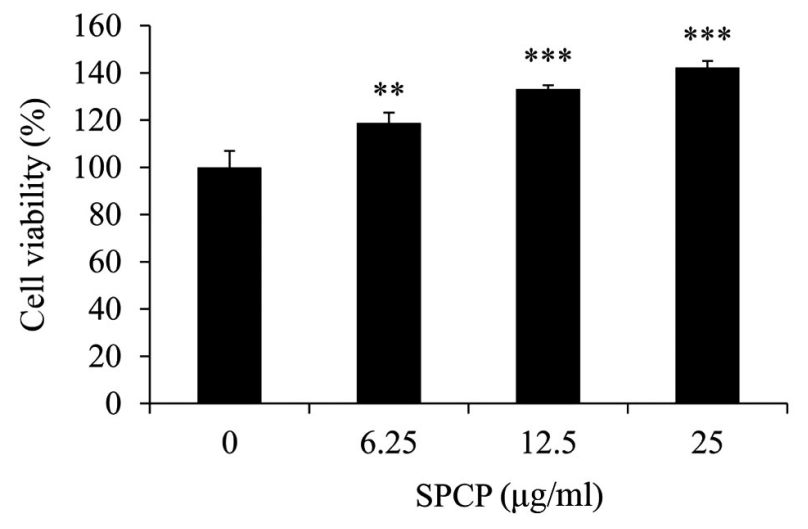

Figure 2. SPCP treatment increases the viability of CCD-986sk cells. Cell viability was determined by the MTS assay following treatment with various concentrations of SPCP for $24 \mathrm{~h}$. Data are presented as the mean \pm standard deviation of three independent experiments; ${ }^{* *} \mathrm{P}<0.01$ and ${ }^{* * *} \mathrm{P}<0.001$ vs. Control $(0 \mu \mathrm{g} / \mathrm{ml})$. SPCP, spirulina crude protein.

tion of the EGFR signaling pathway by SPCP was investigated. The EGFR signaling pathway was assessed by analyzing the total and p-EGFR protein expression levels. The expression levels of p-EGFR significantly increased following treatment of CCD-986sk cells with SPCP ( $\mathrm{P}<0.001$; Fig. 5A). SPCP treatment induced the expression of essential linkers of epidermal growth factor receptors to MAP kinase, including the adaptor proteins SHC and GRB2, and the guanine nucleotide exchange protein, $\mathrm{SOS}(\mathrm{P}<0.01$ or $\mathrm{P}<0.001$; Fig. $5 \mathrm{~B})$. These results indicated that SPCP stimulation may activate the EGFR pathway in a dose-dependent manner.

Activation of the MAPK pathway by SPCP in CCD-986sk cells. To determine whether EGFR activation induced activation of the MAPK signaling pathway, the expression levels of Ras were investigated following treatment with various doses of SPCP for $24 \mathrm{~h}$. The expression levels of Ras significantly increased after SPCP treatment compared with untreated control cells $(\mathrm{P}<0.001$; Fig. 6A). Meanwhile, SPCP also enhanced the phosphorylation and activation of MEK and ERK in a dose-dependent manner $(\mathrm{P}<0.001$; Fig. 6B). Taken together, these results indicated that SPCP treatment stimulated CCD-986sk cell viability by activating the EGFR/MAPK/ERK signaling pathway.

\section{Discussion}

Microalgae proteins currently represent one of the most promising protein sources from food due to their abundant and balanced amino acid composition $(35,36)$. A. platensis is an edible, photosynthetic, spiral-shaped, multicellular blue-green alga that possesses anti-inflammation and antioxidant properties. In the present study, spirulina was extracted with ethanol and $\left(\mathrm{NH}_{4}\right)_{2} \mathrm{SO}_{4}$. This extract (SPCP) contained proteins as determined by Coomassie Brilliant Blue staining. Q-TOF MS/MS analysis showed that the $\sim 16 \mathrm{kDa}$ protein band was C-phycocyanin $\alpha$ chain, which has been reported to have many pharmacological benefits, including anti-inflammatory, antioxidant and anticancer $(34,37)$. The MTS assay showed that SPCP promoted the viability of human fibroblasts in a

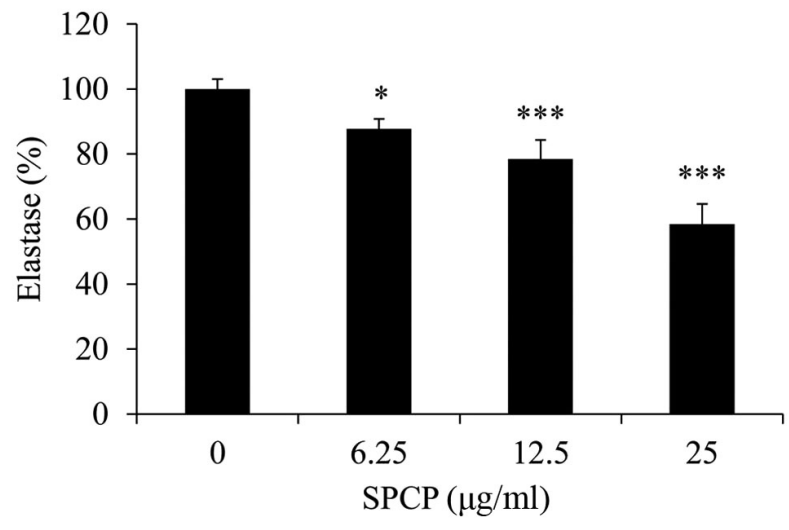

Figure 3. SPCP treatment reduces elastase activity in CCD-986sk cells Elastase activity was determined by ELISA following treatment with various concentrations of SPCP for $24 \mathrm{~h}$. Data are presented as the mean \pm standard deviation of three independent experiments; ${ }^{*} \mathrm{P}<0.05$ and ${ }^{* * *} \mathrm{P}<0.001$ vs. Control $(0 \mu \mathrm{g} / \mathrm{ml})$. SPCP, spirulina crude protein.

dose-dependent manner. Cell viability increased by $18 \pm 4.41 \%$, $33 \pm 1.62 \%$, and $42 \pm 2.82 \%$ associated with the control after treatment with $6.25,12.5$ and $25 \mu \mathrm{g} / \mathrm{ml} \mathrm{SPCP}$, respectively. The results were confirmed by experiments performed in Hs27 cells (data not shown). The present study results suggested that SPCP treatment may lead to skin cell growth by enhancing the activation of growth factors in normal human fibroblasts.

Dermal fibroblasts are the primary cell type responsible for the production, maintenance and remodeling of the ECM in human skin (38). Skin fibrosis and aging are caused by an imbalance between the generation and degradation of ECM proteins, which results in severe alterations in the skin connective tissue (39). Skin aging is associated with a loss of ECM components from the dermis, including collagen, elastin, fibrillin, and proteoglycan (40). The proportion of type I collagen in dermis diminishes with intrinsic and extrinsic skin aging. In the present study, cell collagen production induced by SPCP treatment was 30-142\% higher compared with the control group. The expression levels of the collagen-degrading protein MMP-8, which serves as a key enzyme in the degradation of collagen and stimulates the degradation of other major dermal components (which subsequently leads to aging) (41), was investigated by western blot analysis. These were decreased significantly in a dose-dependent manner in cells treated with SPCP. The increase in collagen might be due to a decrease in the expression of MMP-8, but this needs to be investigated further. Treatment of CCD-986sk cells with SPCP inhibited elastase activity and its activity was reduced in a dose-dependent manner.

Recent advance in understanding the role of endogenous growth factors in the aging process provides opportunities to develop novel anti-aging cosmeceutical products (24). Growth factors can have a prominent role in reversing the outcomes of skin aging (22). Topical application of human growth factors has been shown to reduce the signs and symptoms of skin aging, as well as increase dermal collagen synthesis, in several clinical studies (26). The MTS assay results obtained from the present study, showed that SPCP increased the viability of CCD-986sk cells. In order to explore the mechanism, growth factor protein expression in SPCP-treated CCD-986sk 
A

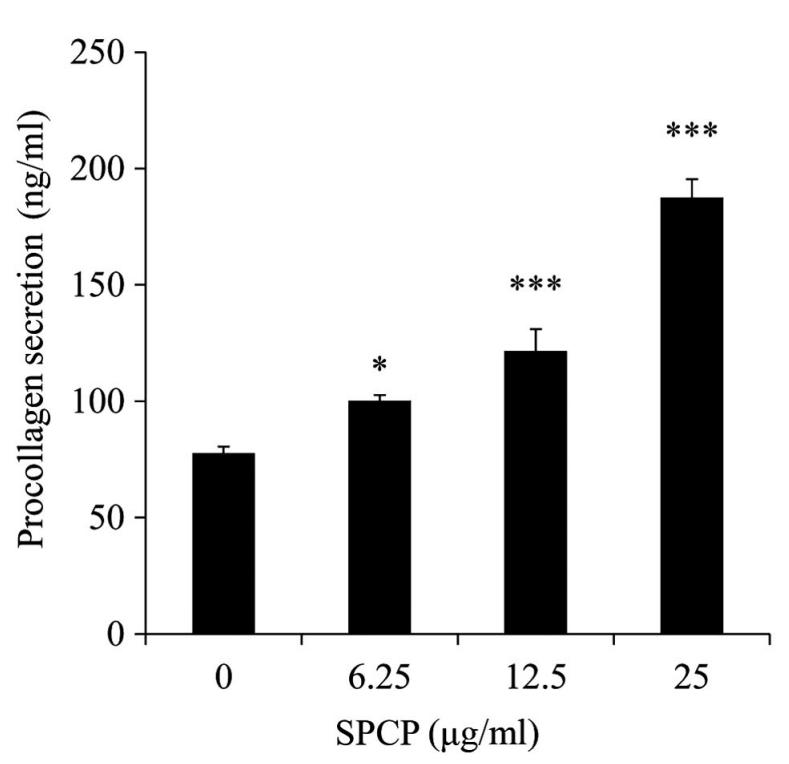

B
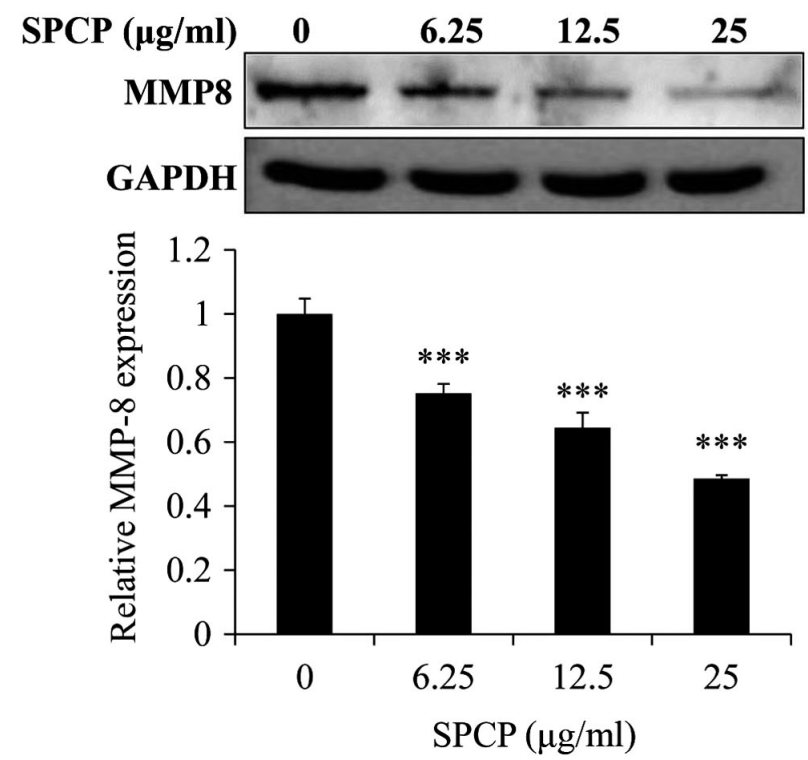

Figure 4. SPCP treatment induces procollagen secretion in CCD-986sk cells. (A) Procollagen secretion was determined using ELISA following treatment with various concentrations of SPCP for $24 \mathrm{~h}$. (B) Changes in MMP-8 protein expression levels were measured by western blotting. Data are presented as the mean \pm standard deviation of three independent experiments; ${ }^{*} \mathrm{P}<0.05$ and ${ }^{* * *} \mathrm{P}<0.001$ vs. Control $(0 \mu \mathrm{g} / \mathrm{ml})$. MMP, matrix metalloprotease; SPCP, spirulina crude protein.

A

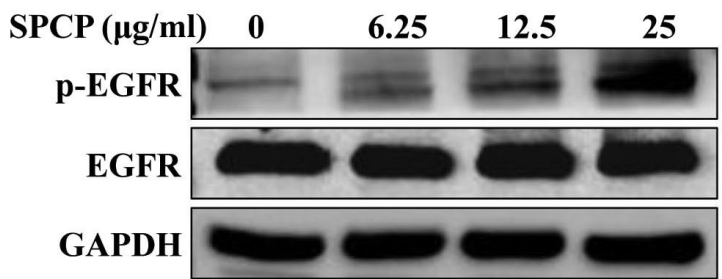

B

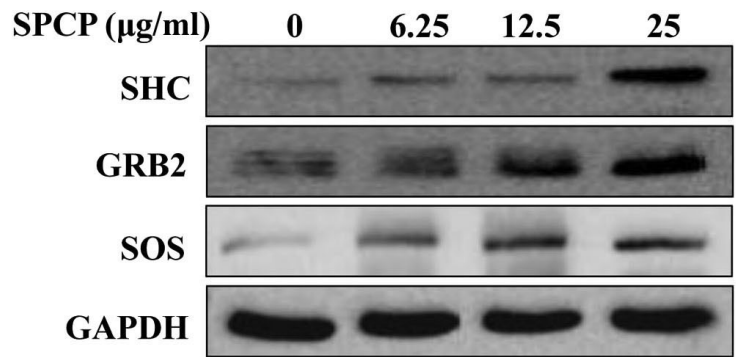

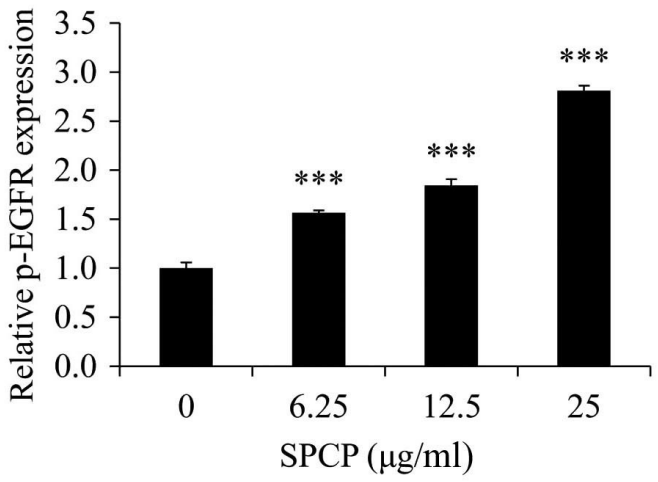

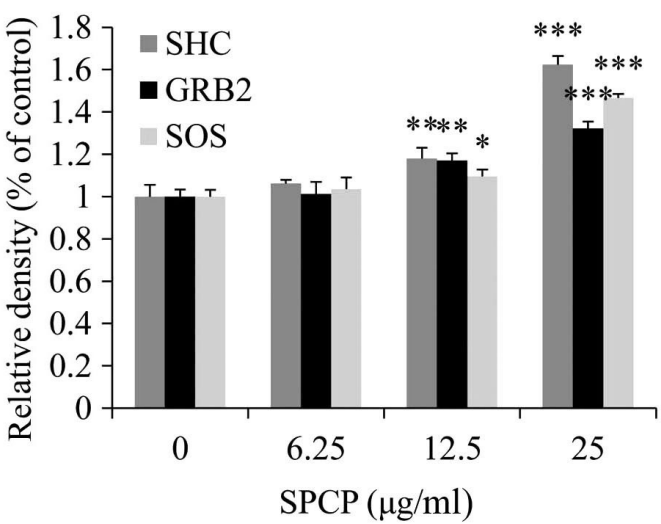

Figure 5. Treatment with SPCP activates the EGFR pathway in CCD-986sk cells. (A and B) CCD-986sk cells were treated with SPCP after incubation with serum-free medium for $4 \mathrm{~h}$ and expression levels of (A) total EGFR and pEGFR, and of (B) SHC, GRB2 and SOS were measured by western blotting. Data are presented as the mean \pm standard deviation of three independent experiments; ${ }^{*} \mathrm{P}<0.05,{ }^{* *} \mathrm{P}<0.01$ and ${ }^{* * * *} \mathrm{P}<0.001 \mathrm{vs}$. Control $(0 \mu \mathrm{g} / \mathrm{ml})$. EGFR, epidermal growth factor receptor; GRB2, growth factor receptor bound protein 2; p, phosphorylated; SOS, son of sevenless homolog; SPCP, spirulina crude protein.

cells were investigated. It is reported that the activation of EGFR and insulin growth factor (IGF)-1R serve an important role in cell proliferation (23). Thus, the activation of EGFR and IGF-1R in CCD-986sk cells was measured. The results showed that EGFR was activated by SPCP rather than IGF-1R (data not shown). Furthermore, EGFR associated with skin 
A

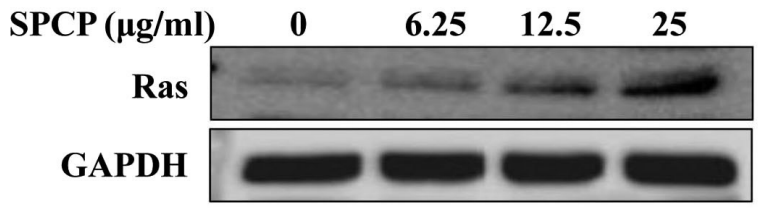

B

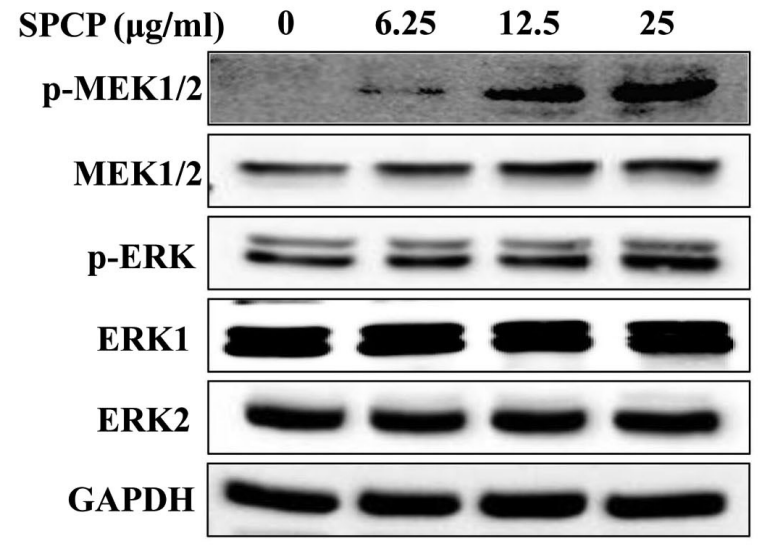

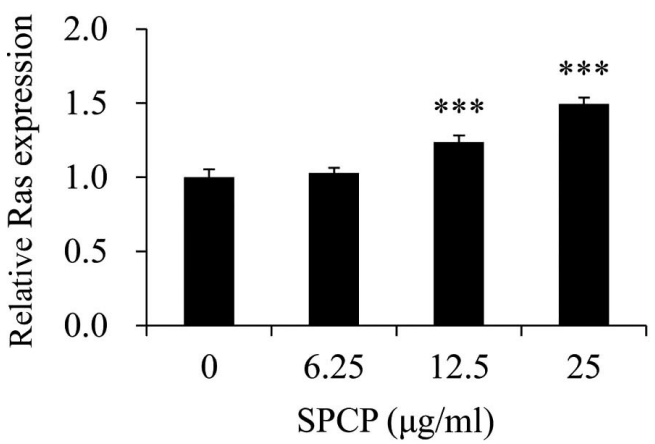

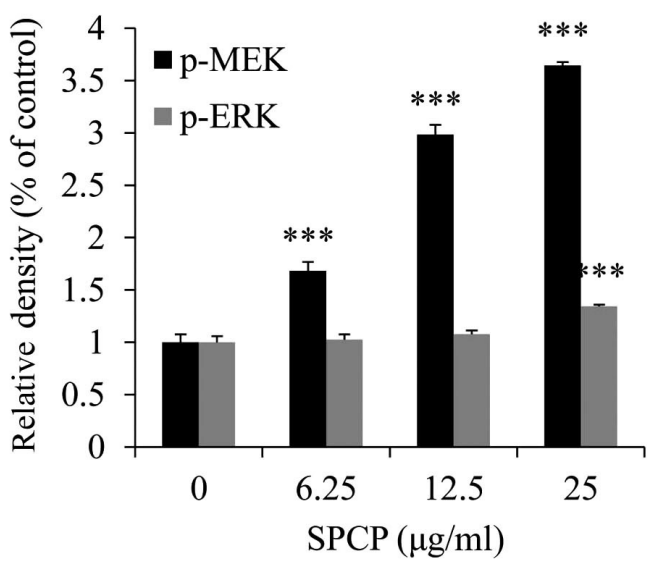

Figure 6. Treatment with SPCP activates the mitogen-activated protein kinase pathway in CCD-986sk cells. (A and B) CCD-986sk cells were treated with various concentrations of SPCP after incubation with serum-free medium for $4 \mathrm{~h}$. Expression levels of (A) Ras and of (B) total and phosphorylated MEK and ERK were measured by western blotting. Data are presented as the mean \pm standard deviation of three independent experiments. ${ }^{* * *} \mathrm{P}<0.001$ vs. Control $(0 \mu \mathrm{g} \mathrm{ml})$. ERK, extracellular signal-regulated kinase; MEK, mitogen-activated protein kinase kinase; p, phosphorylated; SPCP, spirulina crude protein.

aging (21). Based on the present data, it was found that SPCP enhanced the secretion of PIP and inhibited the activity of elastase. These results are beneficial for delaying skin aging. In the present study, p-EGFR was increased in SPCP-treated cells compared with the control cells. Additionally, the essential linkers from epidermal growth factor receptors to MAP kinase, including the adaptor proteins GRB2, SHC and SOS, were induced by SPCP treatment in a dose-dependent manner. These data indicated that SPCP stimulation induced EGFR pathway activation in a dose-dependent manner. A previous study reported that one of the main activated downstream signaling pathways is the MEK-ERK1/2 signaling pathway, which controls cell proliferation and differentiation (42). There are three proteins [ERK, c-Jun N terminal kinase (JNK) and p38] in MAPK signaling pathway (43). Only ERK1 and ERK2 are activated in response to growth factors, whereas JNK and p38 are more responsive to environmental stresses and inflammatory cytokines (44). The activation of this downstream signaling pathway was investigated and Ras levels were increased in SPCP treated cells, followed by phosphorylation and activation of MEK and ERK in a dose-dependent manner. The phosphorylation of ERK serves an important role in regulation of cell proliferation (43).

In summary, the expression levels of both MMP-8 protein and elastase were decreased by SPCP, leading to increased collagen levels. Additionally, SPCP treatment activated the EGFR and MAPK/ERK signaling pathways. To demonstrate the reproducibility of these results, other human dermal fibroblasts derived from different donors, such as different age and gender will be used for further experiments. Based on these findings, it seems that the viability of human dermal fibroblasts was activated by SPCP. Overall, these results suggest that SPCP may be used as a cosmeceutical for potential applications in protecting human skin; however, further investigation is required. To further determine the effects of SPCP, hairless mice should be used to explore the change of epidermal thickness and collagen fibers with the application of SPCP.

\section{Acknowledgements}

Not applicable.

\section{Funding}

The present study was supported by the Basic Science Research Program through the National Research Foundation of Korea, funded by the Ministry of Education (grant no. 2012R1A6A1028677).

\section{Availability of data and materials}

The analyzed data sets of the present study are available from the corresponding author on reasonable request.

\section{Authors' contributions}

PL, YHC and TJN made substantial contributions to the conception and design of this study; PL, MKL and JWC performed the 
experiments; PL, MKL and YHC performed the data analysis; $\mathrm{PL}$ and YHC interpreted the experimental results and wrote the manuscript. All authors read and approved the final manuscript and agreed to the publication of the final manuscript.

\section{Ethics approval and consent to participate}

Not applicable.

\section{Patient consent for publication}

Not applicable.

\section{Competing interests}

The authors declare that they have no competing interests.

\section{References}

1. Wu X, Li R, Zhao Y and Liu Y: Separation of polysaccharides from Spirulina platensis by HSCCC with ethanol-ammonium sulfate ATPS and their antioxidant activities. Carbohydr Polym 173: 465-472, 2017.

2. Vo TS, Ngo DH, Kang KH, Park SJ and Kim SK: The role of peptides derived from Spirulina maxima in downregulation of FceRI-mediated allergic responses. Mol Nutr Food Res 58: 2226-2234, 2014.

3. Wang B, Cai T, Liu Q, Whitney JCC, Du M, Ma Q, Zhang R, Yang L, Cole SPC and Cai Y: Preparation and evaluation of spirulina polysaccharide nanoemulsions. Int J Mol Med 42: 1273-1282, 2018.

4. Yogianti F, Kunisada M, Nakano E, Ono R, Sakumi K, Oka S, Nakabeppu Y and Nishigori C: Inhibitory effects of dietary Spirulina platensis on UVB-induced skin inflammatory responses and carcinogenesis. J Invest Dermatol 134: 2610-2619, 2014

5. Wu Q, Liu L, Miron A, Klímová B, Wan D and Kuča K: The antioxidant, immunomodulatory, and anti-inflammatory activities of Spirulina: An overview. Arch Toxicol 90: 1817-1840, 2016.

6. Nawrocka D, Kornicka K, Śmieszek A and Marycz K: Spirulina platensis improves mitochondrial function impaired by elevated oxidative stress in adipose-derived mesenchymal stromal cells (ASCs) and intestinal epithelial cells (IECs), and enhances insulin sensitivity in equine metabolic syndrome (EMS) horses. Mar Drugs 15: 237, 2017.

7. Vázquez-Velasco M, González-Torres L, López-Gasco P, Bastida S, Benedí J, Sánchez-Reus MI, González-Muñoz MJ and Sánchez-Muniz FJ: Liver oxidation and inflammation in $\mathrm{Fa} / \mathrm{Fa}$ rats fed glucomannan/spirulina-surimi. Food Chem 159: 215-221, 2014

8. Al-Dhabi NA and Valan Arasu M: Quantification of phytochemicals from commercial Spirulina products and their antioxidant activities. Evid Based Complement Alternat Med 2016: 1-13, 2016.

9. Spolaore P, Joannis-Cassan C, Duran E and Isambert A: Commercial applications of microalgae. J Biosci Bioeng 101: 87-96, 2006.

10. Kim SK, Ravichandran YD, Khan SB and Kim YT: Prospective of the cosmeceuticals derived from marine organisms. Biotechnol Bioproc E 13: 511-523, 2008.

11. Xiong ZM, O'Donovan M, Sun L, Choi JY, Ren M and Cao K Anti-aging potentials of methylene blue for human skin longevity. Sci Rep 7: 2475, 2017.

12. Hoseini SM, Kalantari A, Afarideh M, Noshad S, Behdadnia A, Nakhjavani M and Esteghamati A: Evaluation of plasma MMP-8, MMP-9 and TIMP-1 identifies candidate cardiometabolic risk marker in metabolic syndrome: Results from double-blinded nested case-control study. Metabolism 64: 527-538, 2015.

13. Tundis R, Loizzo MR, Bonesi M and Menichini F: Potential role of natural compounds against skin aging. Curr Med Chem 22: $1515-1538,2015$.

14. Pham QL, Jang HJ and Kim KB: Anti-wrinkle effect of fermented black ginseng on human fibroblasts. Int J Mol Med 39: 681-686, 2017.
15. Na J, Bak DH, Im SI, Choi H, Hwang JH, Kong SY, No YA, Lee Y and Kim BJ: Anti-apoptotic effects of glycosaminoglycans via inhibition of ERK/AP-1 signaling in TNF- $\alpha$-stimulated human dermal fibroblasts. Int J Mol Med 41: 3090-3098, 2018.

16. Meinke MC, Nowbary CK, Schanzer S, Vollert H, Lademann J and Darvin ME: Influences of orally taken carotenoid-rich curly kale extract on collagen I/elastin index of the skin. Nutrients 9: 775, 2017.

17. Rittié L and Fisher GJ: UV-light-induced signal cascades and skin aging. Ageing Res Rev 1: 705-720, 2002.

18. Jadoon S, Karim S, Bin Asad MH, Akram MR, Khan AK, Malik A, Chen $\mathrm{C}$ and Murtaza G: Anti-aging potential of phytoextract loaded-pharmaceutical creams for human skin cell longevity. Oxid Med Cell Longev 2015: 709628, 2015.

19. Herman MP, Sukhova GK, Libby P, Gerdes N, Tang N, Horton DB, Kilbride M, Breitbart RE, Chun M and Schönbeck U: Expression of neutrophil collagenase (matrix metalloproteinase-8) in human atheroma: A novel collagenolytic pathway suggested by transcriptional profiling. Circulation 104: 1899-1904, 2001.

20. Burke KE: Mechanisms of aging and development-A new understanding of environmental damage to the skin and prevention with topical antioxidants. Mech Ageing Dev 172: 123-130, 2018.

21. Shiraha H, Gupta K, Drabik K and Wells A: Aging fibroblasts present reduced epidermal growth factor (EGF) responsiveness due to preferential loss of EGF receptors. J Biol Chem 275: 19343-19351, 2000.

22. Chen J, Li Y, Zhu Q, Li T, Lu H, Wei N, Huang Y, Shi R, Ma X, Wang X, et al: Anti-skin-aging effect of epigallocatechin gallate by regulating epidermal growth factor receptor pathway on aging mouse model induced by d-Galactose. Mech Ageing Dev 164: $1-7,2017$

23. Gao M, Zhan YQ, Yu M, Ge CH, Li CY, Zhang JH, Wang XH, Ge ZQ and Yang XM: Hepassocin activates the EGFR/ERK cascade and induces proliferation of L02 cells through the Src-dependent pathway. Cell Signal 26: 2161-2166, 2014.

24. Gerber PA, Buhren BA, Schrumpf H, Hevezi P, Bölke E, Sohn D, Jänicke RU, Belum VR, Robert C, Lacouture ME, et al: Mechanisms of skin aging induced by EGFR inhibitors. Support Care Cancer 24: 4241-4248, 2016.

25. Green MR, Basketter DA, Couchman JR and Rees DA: Distribution and number of epidermal growth factor receptors in skin is related to epithelial cell growth. Dev Biol 100: 506-512, 1983.

26. Tran KT, Rusu SD, Satish L and Wells A: Aging-related attenuation of EGF receptor signaling is mediated in part by increased protein tyrosine phosphatase activity. Exp Cell Res 289: 359-367, 2003.

27. Zhang W and Liu HT: MAPK signal pathways in the regulation of cell proliferation in mammalian cells. Cell Res 12: 9-18, 2002.

28. Li Z, Liu S and Cai Y: EGFR/MAPK signaling regulates the proliferation of Drosophila renal and nephric stem cells. J Genet Genomics 42: 9-20, 2015.

29. Shin S, Son D, Kim M, Lee S, Roh KB, Ryu D, Lee J, Jung E and Park D: Ameliorating effect of akebia quinata fruit extracts on skin aging induced by advanced glycation end products. Nutrients 7: 9337-9352, 2015

30. Ryu J, Kwon MJ and Nam TJ: Nrf2 and NF- $x$ B signaling pathways contribute to porphyra-334-mediated inhibition of UVA-induced inflammation in skin fibroblasts. Mar Drugs 13: 4721-4732, 2015.

31. Barnes D and Sato G: Methods for growth of cultured cells in serum-free medium. Anal Biochem 102: 255-270, 1980

32. Kim YM, Jung HJ, Choi JS and Nam TJ: Anti-wrinkle effects of a tuna heart $\mathrm{H}_{2} \mathrm{O}$ fraction on $\mathrm{Hs} 27$ human fibroblasts. Int $\mathrm{J}$ Mol Med 37: 92-98, 2016.

33. Magadum A, Ding Y, He L, Kim T, Vasudevarao MD, Long Q, Yang K, Wickramasinghe N, Renikunta HV, Dubois N, et al: Live cell screening platform identifies PPARS as a regulator of cardiomyocyte proliferation and cardiac repair. Cell Res 27: 1002-1019, 2017.

34. Lee J, Park A, Kim MJ, Lim HJ, Rha YA and Kang HG: Spirulina extract enhanced a protective effect in type 1 diabetes by anti-apoptosis and anti-ROS production. Nutrients 9: 1363, 2017.

35. Lu J, Ren DF, Wang JZ, Sanada H and Egashira Y: Protection by dietary Spirulina platensis against D-galactosamine--and acetaminophen-induced liver injuries. Br J Nutr 103: 1573-1576, 2010.

36. Kepekçi RA, Polat S, Çelik A, Bayat N and Saygideger SD: Protective effect of Spirulina platensis enriched in phenolic compounds against hepatotoxicity induced by CCl4. Food Chem 141: 1972-1979, 2013. 
37. Romay Ch, González R, Ledón N, Remirez D and Rimbau V: C-phycocyanin: A biliprotein with antioxidant, anti-inflammatory and neuroprotective effects. Curr Protein Pept Sci 4 207-216, 2003

38. Kim MS, Song HJ, Lee SH and Lee CK: Comparative study of various growth factors and cytokines on type I collagen and hyaluronan production in human dermal fibroblasts. J Cosmet Dermatol 13: 44-51, 2014

39. Tanaka M, Koyama Y and Nomura Y: Effects of collagen peptide ingestion on UV-B-induced skin damage. Biosci Biotechnol Biochem 73: 930-932, 2009.

40. Kim MK, Bang CY, Yun GJ, Kim HY, Jang YP and Choung SY: Anti-wrinkle effects of Seungma-Galgeun-Tang as evidenced by the inhibition of matrix metalloproteinase-I production and the promotion of type-1 procollagen synthesis. BMC Complement Altern Med 16: 116, 2016.

41. Zhang CY, Li XH, Zhang T, Fu J and Cui XD: Hydrogen sulfide suppresses the expression of MMP-8, MMP-13, and TIMP-1 in left ventricles of rats with cardiac volume overload. Acta Pharmacol Sin 34: 1301-1309, 2013.
42. Corcoran RB, Ebi H, Turke AB, Coffee EM, Nishino M, Cogdill AP, Brown RD, Della Pelle P, Dias-Santagata D, Hung KE, et al: EGFR-mediated re-activation of MAPK signaling contributes to insensitivity of BRAF mutant colorectal cancers to RAF inhibition with vemurafenib. Cancer Discov 2: 227-235, 2012.

43. Pearson G, Robinson F, Beers Gibson T, Xu BE, Karandikar M, Berman K and Cobb MH: Mitogen-activated protein (MAP) kinase pathways: Regulation and physiological functions. Endocr Rev 22: 153-183, 2001.

44. Roux PP and Blenis J: ERK and p38 MAPK-activated protein kinases: A family of protein kinases with diverse biological functions. Microbiol Mol Biol Rev 68: 320-344, 2004.

This work is licensed under a Creative Commons Attribution-NonCommercial-NoDerivatives 4.0 International (CC BY-NC-ND 4.0) License. 